\title{
Sexual Harassment on Senior Highschool Female Students
}

\author{
Rosyidatul Lathifah, Suwarti*, Roseyoana Logisian Subekti \\ Faculty of Psychology, Universitas Muhammadiyah Purwokerto, Jl. KH. Ahmad Dahlan, Purwokerto, Indonesia. \\ *Corresponding author: suwarti@ump.ac.id
}

Article history: Received: 11 January 2020 Received in revised form: 28 June 2020 Accepted: 10 May 2021 Published online: 09 August 2021

\begin{abstract}
This research aims to determine sexual harassment on senior high school female students. The subjects of this research were 40 senior high school female students in Purwokerto, Banyumas, Central Java, as many as 40 people were selected using random sampling. Analysis of the data used is a descriptive analysis of the test categories through the help of SPSS 20.00 for windows. The results of the analysis show a range score of 109, a minimum score of 55, a maximum score of 164 , a mean score of 98.37, a standard deviation score of 27.26 and a variant score of 743.112. Based on the results obtained from the data collection, the category of subjects of sexual harassment on senior high school female students in Purwokerto was very high at 1 subject or $2.5 \%$, high at 10 subjects or $25 \%$, medium at 18 subjects or $45 \%$, low at 7 subjects or $17.5 \%$ and very low by 4 subjects or $10 \%$.
\end{abstract}

Keywords: Sexual Harassment; Female Students.

(C) 2021 Penerbit UTM Press. All rights reserved

\subsection{INTRODUCTION}

The definition of adolescent that is not too easy to explain precisely, because there are many researchers who define it, one of the characters defines adolescents from the Latin language which is adolscene which means English to grow maturity which explains that adolescents will always grow to adulthood (Glinko, 1984). Adolescence is a transition from childhood to adulthood which experiences the development of all aspects/ functions to enter adulthood when the individual wants to be said as a teenager according Rumini and Sundari, (2004).

Havighurst (in Wijayanti, 2013) states that if the task of adolescent development is a series of tasks that arise in certain periods (age range) in individual lives, if the task is successfully completed it will bring individuals to happiness and success in completing the next task.

Supposedly, adolescents who can carry out developmental tasks properly, will certainly be able to pass through their teenage years smoothly. If the development task can be successfully completed it will bring happiness and success in completing the next task according Potter (in Rahmah, 2016).

The results of a preliminary study on subject $\mathrm{A}$ in which the subject included one of female student at a senior high school in Purwokerto. Subject A describes the experiences of subjects who are victims of sexual harassment by male school friends in the form of verbal behavior which is given a call that she doesn't liked by the subject such as lack of subject. Then the subject also received non-verbal harassment in the form of making gestures touching organs, getting whistles and eye teasing by the opposite sex. The sexual harassment behavior refers to the subject's fears so that the subject feels tense, the heart beats fast, but the expression that is displayed is only the attitude of not caring but actually scared. And this usually happened in front of her class when school breaks (Monday 23rd of September 2019).

On the other hand, the researchers also continued to interview subject B who were both in school with subject A. Subject B claimed to have experienced verbal harassment. Which the subject had received a call where the call made subject B very embarrassed, then subject B also often got a body shaming from her friends by the opposite sex. Subject B also had a compulsion to have a relationship with his classmates, however, subject B tried to refuse because the person was disliked by subject B. Subject B felt a chill, fear so that he felt anxious and there was a sense of insecurity on his own (Monday 23rd September 2019).

The preliminary study above supports the results of research by YouGov (2014), explaining that Jakarta discusses the assessment of cities with the highest level of verbal harassment against women, especially in public transportation. In 2016 ActionAid conducted a survey on street harassment in the state. ActionAid found that $75 \%$ of women in London, $79 \%$ of women living in cities in India, $86 \%$ in Thailand, and $89 \%$ in Brazil had experienced public harassment or violence.

Sexual harassment behavior that is considered a form of "eye teasing" includes making gestures touching organs, obscene movements, whistling, staring, pinching, fondling, and poking a woman Fairchild (2010) have noted that street harassment is divided into many common themes with sexual harassment that occurs in other contexts especially components of unwanted sexual attention. 
Data from the Equal Employment Opportunity Commission (EEOC) defines sexual harassment in terms of victims' perceptions regarding frequency, coercion, and accuracy (Fairchild, 2010). Harassment is in the eye of the beholder in other words, it is up to the victim to label the harassment of behavior. Sexual harassment is a matter of individual perception. This shows that there are many potential individual and situational variables that can influence the perception of harassment. The data was strengthened by the National Commission on Violence Against Women (in Dewi, 2019) in 2017 there were 348,446 recorded cases of violence against women, 26\% or 3,528 cases occurred in the public sphere. Data obtained by the National Commission on Violence Against Women based on a questionnaire, shows an increase in cases of violence against women by $25 \%$ compared to 2016 . Cases of violence against women in public spaces recorded in 2017 , there were as many as sexual harassment (704 cases).

The data above is strengthened by the results of the research that explains sexual harassment generally occurs against women, although in one or two rare cases, there are also men who are victims. Gutek's research in Unger and Crawford (in Zainal, 2014) concluded that more women (53\%) experienced sexual harassment than men (35\%).

This is reinforced by the most common form of sexual harassment is gender harassment, which involves comments, jokes, and sexual and demeans victims based on sex rather than requesting sexual relations with them. According to Fitzgeraldetal, 1988 (in Berdahl 2007). So the impact of sexual harassment explained in theory Livingston (in Saunders 2016) found that, of 4872 American women-85\% first experienced some form of foreigner harassment before the age of 17, and that foreigner harassment had a real impact on women's behavior, due to experience Foreigner harassment has prompted women to change their transportation. routes or facilities (85\% of respondents), avoiding certain cities or regions as a whole (72\%), avoiding going out at night (70\%), and changing socialization patterns to avoid certain people $(63 \%)$.

The outline discussed in this research the problem of adolescents, which is related to sexual harassment, which by definition is a behavior that is generally carried out by men to a woman in sexual matters which are disliked by the victim because the victim feels insulted, but if sexual treatment is refused then the impact going bad according Mboiek, Stanko, (in Fuadi, 2011).

This research is important in popular culture and relative in visibility in scholarly literature, street harassment is aprevalent phenomenon that has extremely negative short- and long-term impacts on its individual targets, including shame, anger, restricted mobility, depression, reduced self-esteem, self-objectification, anxiety, and fear of navigating public spaces according Lord (in Lennox, 2017).

Previously this important research had been carried out to determine social norms and cultural risk factors associated with sexual harassment both in the educational environment and in the workplace (Galdi et al., 2014). In other word the results of research from Galdi that currently sexual harassment apparently does not only exist in the world of work again but has spread to the world of education as well.

We know from some researchers that discussed if sexual harassment has impact on women and some of them is students. So, the researcher is interesting for doing the quantitative research with finding how much the impact and the categories or classification of women who get the sexual harassment. So those researchers are interested in researching about sexual harassment in female high school students in Purwokerto.

\subsection{LITERATURE REVIEW}

\section{Sexual Harassment}

The definition of sexual harassment can be defined as a criminal law of sexual discrimination and includes inappropriate behavior such as physical violence, emotional violence, and acts of violence according to Butterfield (1995). This is reinforced by the theory of Berdahl (2007). Sexual harassment also means such as sexual disorder, it has a very wide range, starting from verbal expressions (like give some bad comments, jokes etc.) include are dirty word / not profanity, indecent behavior (poke, touch, poke, hug and etc.), show pornographic content / dirty images, assault and coercion who don't like profanity, they will force it for kiss or hug, threaten make it difficult for a woman if she refuses to provide sexual services, until rape, this statement from Sumera (2013). Which states that sexual harassment is "demeaning behavior, or insulting someone based on the sex of the individual". The latest theory from Tenbrunsel (2018) explains that sexual harassment is an unwanted sexual will, requests for sexual assistance, verbal or physical harassment of a sexual nature, or offensive comments about a person's sex. The aspect of sexual harassment in the triparti model that is widely accepted by sexual harassment from Fitzgerald (in Burn 2019) identifies three dimensions of behavior: gender harassment, unwanted sexual attention, and sexual coercion.

\section{Gender Harassment}

Gender harassment refers to abusive verbal and nonverbal sexual behavior that conveys an insulting, hostile, and degrading attitude about a person's gender, gender identity, or sexual orientation. Inappropriate sexual movements, flickering, displaying sexual images or objects at work, and sending e-mails or texting sexual pictures to coworkers or coworkers are all forms of gender harassment. Sexist or heterosexist languages, jokes, or comments are also included in this title.

\section{Sexual Attention}

Unwanted sexual attention includes making suggestive or positive and negative comments about a person's body, glancing and calling, spreading sexual rumors about someone, and electronically sharing someone's sexual images. Unwanted sexual touches, such as reaching, pinching, groping, deliberately brushing someone else in a sexual manner, are also considered to be unwanted sexual attention. This also applies to blocking other people's paths or following someone sexually, unsolicited, unwelcome, and not prescribed sexual advances such as repeated requests for kissing, dating, or sex; and try or resolve rape. 


\section{Sexual Coercion}

Sexual coercion known legally as a quid pro quo sexual harassment refers to requiring sexual contact or sexual assistance as a condition of receiving gifts or benefits such as employment, promotion, favorable working conditions, assistance, or evaluation or good performance levels. Although sexual coercion seems to be the most serious and most common form of sexual harassment, the less intense but more frequent form of sexual harassment can create ongoing stress and trauma that damage welfare

While as according to Law RI SISDIKNAS No. 20 of 2003, explained that students are all human beings, which at the same time can be both educators and students.

\subsection{METHODOLOGY}

\section{Respondents}

Research subjects were 40 female students on senior high school in Purwokerto, Central Java, Indonesia. This research uses quantitative research methods. The sampling technique used in this study is simple random sampling.

\section{Research Instruments}

This research data collection tool uses the SEQ (Sexual Experience Questionnaire) Scale which the researcher has modified with 3 aspects, there are gender harassment, unwanted sexual desire and sexual coercion. The initial items used by researchers were 44 items as shown on the Table 1 below.

Table 1 Sexual harassment item flyer on female students on senior high schools in Purwokerto

\begin{tabular}{ccccc}
\hline \multirow{2}{*}{ NO. } & \multirow{2}{*}{ ASPECTS } & \multicolumn{2}{c}{ NUMBER OF ITEM } & \multirow{2}{*}{ TOTAL } \\
\cline { 3 - 5 } & & Favorable & Unfavorable & \\
\hline \multirow{2}{*}{ Gender Harassment } & $1,7,13,19,25,31,35,40,4$ & $4,10,16,22,29,33,3$ & 17 \\
& & 3 & 8,42 & 17 \\
\hline \multirow{2}{*}{} & Unwanted Sexual & $2,8,14,20,26,32,37,39,4$ & $5,11,17,23,30,34,3$ & 10 \\
\hline \multirow{2}{*}{$\mathbf{3}$} & Desire & 4 & 6,41 & 44 \\
\hline
\end{tabular}

As shown on the Table 2 The Test of validity from 44 items with favorable 22 items and unfavorable 22 items. Fall 4 items are items $3,7,14$ and 44 . In this study the validity presentation was only carried out on 40 respondents. Decision making is based on the calculated value (Corrected Item-Total Correlation) $>\mathrm{r}$ table of 0.263 for $\mathrm{df}=40-2=38 ; \alpha=0.05$ then the item/ statement is valid. The reliability coefficient using alpha cronbach was 0.748 .

Table 2 Sexual harassment item flyer on female students on senior high schools in Purwokerto after disposal

\begin{tabular}{|c|c|c|c|c|}
\hline \multirow{2}{*}{ NO } & \multirow{2}{*}{ ASPECTS } & \multicolumn{2}{|c|}{ NUMBER OF ITEM } & \multirow{2}{*}{ TOTAI } \\
\hline & & Favorable & Unfavorable & \\
\hline \multirow[t]{2}{*}{1} & Gender Harassment & $1,13,19,25,31,35,40,43$ & $4,10,16,22,29,33,3$ & 16 \\
\hline & & & 8,42 & \\
\hline \multirow[t]{2}{*}{2} & Unwanted Sexual & $2,8,20,26,32,37,39$ & $5,11,17,23,30,34,3$ & 15 \\
\hline & Desire & & 6,41 & \\
\hline \multirow[t]{2}{*}{3} & Sexual Coercion & $9,15,21,28$ & $6,12,18,24$ & 9 \\
\hline & TOTAL & 18 & 22 & 40 \\
\hline
\end{tabular}

Data is collected using a proven scale method (Azwar, 2010). This scale consists of 4 alternative answers from the Likert scale response format with four answer choices including Always (SL), Often (SE), Sometimes (KD), Rarely (JR), Never (TP). Analysis of the data used is a descriptive analysis of the test categories through the help of SPSS 20.00 for windows.

\subsection{RESULTS}

The analysis process uses SPSS version 20.00 for windows. Analysis of the data used is category descriptive analysis. 
Table 3 Descriptive statistics

\begin{tabular}{llllllll} 
& N & Range & Minimum & Maximum & Mean & Std. Deviation & Variance \\
\hline Class & 40 & 2 & 1 & 3 & 1.38 & .628 & .394 \\
\hline A_TOT & 40 & 109 & 55 & 164 & 98.37 & 27.260 & 743.112 \\
\hline Valid N (listwise) & 40 & & & & & & \\
\hline
\end{tabular}

Table 4 Data distribution of sexual harassment on senior high school female students

\begin{tabular}{clcc}
\hline Score Range & Categorize & Frequency & (\%) \\
\hline Very high & $\mathrm{X}>147,43$ & 1 & 2.5 \\
\hline High & $114,72<=\mathrm{X}<147,43$ & 10 & 25 \\
\hline Medium & $82,01<=\mathrm{X}<114,72$ & 18 & 45 \\
\hline Low & $49,3<=\mathrm{X}<82,01$ & 7 & 17.5 \\
\hline Very low & $\mathrm{X}<49,3$ & 4 & 10 \\
\hline & TOTAL & $\mathbf{4 0}$ & $\mathbf{1 0 0}$
\end{tabular}

Based on the results, explanation of table 3 is descriptive statistics results of research on 40 high school female students with sexual harassment variables have a range or distance between the maximum value and minimum value of 109 , with the lowest value of 55 , the highest value of 164, the average value is 98.37, the standard deviation (level of data distribution) is 27.26, the value obtained from the division of the sum of squares with the size of the data (n) is 743,112 . Then from table 4 , obtained from the data collection, the category of subjects of sexual harassment in high school female students in Purwokerto was very high at 1 subject or $2.5 \%$, high at 10 subjects or $25 \%$, medium at 18 subjects or $45 \%$, low at 7 subjects or $17.5 \%$ and very low by 4 subjects or $10 \%$.

\subsection{DISCUSSION}

The results of data analysis show that in Table 3 can be seen that the results of research on 40 high school female students with sexual harassment variables have a range or distance between the maximum value and minimum value of 109 , with the lowest value of 55, the highest value of 164, the average value is 98.37 , the standard deviation (level of data distribution) is 27.26, the value obtained from the division of the sum of squares with the size of the data (n) is 743,112 .

This study explains the sexual harassment of female high school female students in Purwokerto that from 40 respondents whose sexual harassment rate was very high there was 1 subject (2.5\%), 10 subjects high (25\%), while 18 subjects $(45 \%)$, as low as 7 subjects $(17.5 \%)$ and very low as many as 4 subjects $(10 \%)$.

This research is in line with the results of the preliminary study conducted by researchers through a Google form which with the participation of 8 subjects of high school female students which was held in September 2019 in the same place, then the results of the online questionnaire explained his diagram that $50 \%$ had experienced a "pretty" call from a man while walking, then $100 \%$ had received greetings from a man, then $37.5 \%$ had had a whistle from a man, $25 \%$ of whom had experienced a sexual thing. through verbal, then $62.5 \%$ ever get a wink from a man and the last $37.5 \%$ ever get behavior such as being held in a part of his body by a man. This research also supporting the result of research from Gender Study Group in Delhi (in Dhillon, 2014), 45\% of women said that sexual harassment on campus affected their personal or academic development in some way such as avoiding library facilities, not joining various institutions, and avoiding particular courses.

Those data supported by the results of research from Nurudin (2010) which explains that female adolescents in interpreting sexual harassment, the majority of adolescents and the community provide a narrow understanding about it. Then sexual harassment is only a form of physical violence, while there are very few interpretations as a form of harassment caused by a social system of society as a whole.

While such adolescent perception influences the characteristics of awareness in responding to acts of sexual harassment among adolescents. Specifically, there have not been any special efforts from female students in responding to existing problems. The impact, is many acts of sexual harassment that occur have not become a concern and concern expressed in a social solidarity.

\subsection{CONCLUSION}

Conclusion Based on the results of the descriptive analysis test the category is then classified. the results of this study explain sexual harassment in female high school students in Purwokerto that of the 40 respondents whose sexual harassment rates were very high there was 1 subject $(2.5 \%)$, high as high as 10 subjects $(25 \%)$, medium were 18 subjects $(45 \%)$, low by 7 subjects $(17.5 \%)$ and very low by 4 subjects $(10 \%)$. 


\section{References}

Berdahl L J and Raver, J L. (2007). Sexual Harassment. Z- lib. Journal of Applied Psychology, 92(2), 425.

Burn, S M. (2019). The Psychology of Sexual Harassment. Society for the Teaching of Psychology, 46(1), 96-103.

Butterfield. (1995). Sexual Harassment and Discrimination. Z-lib

Dewi, I.A.A. (2019). Catcalling: Candaan, Pujian Atau Pelecehan Seksual. ACTA COMITAS Jurnal Hukum Dan Kenotariatan, 4(2), 198-212.

Dhillon, M., and Bakaya, S. (2014). Street Harassment: A Qualitative Study of the Experiences of Young Women in Delhi. sgo.sagepub.com SAGE. 1 -11. DOI: $10.1177 / 2158244014543786$

Fairchild, K. (2010). Context Effects on Women's Perceptions of Stranger Harassment. Sexuality \& Culture. DOI 10.1007/s12119-010-9070-1

Fuadi, M.A. (2011). Dinamika Psikologis Kekerasan Seksual: Sebuah Studi Fenomenologi. Jurnal Psikologi Islam (JPI), 8(2), 191-208.

Galdi, S. Maass, A and Cardinu, M. (2014). Objectifying Media: Their Effect on Gender Role Norms and Sexual Harassment of Women. Psychology of Women Quarterly, 38(3), 398-413? DOI: 10.1177/0361684313515185

Lennox, R. \& Hage, R.J. (2017). Beyond The Empirical and The Discursive: The Methodological Implications of Critical Realism for Street Harassment Research. Women'S Studies International Forum, 66(28), 28-38.

Nurudin. (2010). Studi Deskriptif Kualitatif Mengenai Pemaknaan Remaja Perempuan Tentang Tindakan Pelecehan Seksual Di Kabupaten Klaten. Surakarta: Fakultas Ilmu Sosial dan Ilmu Politik. Universitas Sebelas Maret.

Putro, K.Z. (2017). Memahami Ciri dan Tugas Perkembangan Masa Remaja. Aplikasia: Jurnal Aplikasi Ilmiah-ilmiah Agama, 17(1), 25-32.

Rahmah, E.R.W. (2016). Hubungan Peran Ayah Terhadap Pemenuhan Tugas Perkembangan Remaja. Jurnal Kebidanan dan Keperawatan, 12(2),173-180.

Saunders, B.A. Guarito, C. \& Kelly, E. (2016). Contending with Catcalling:The Role of System-justifying Beliefs and Ambivalent Sexism in Predicting Women's Coping Experiences with (and Men's Attributions for) Stranger Harassment. Current Opinion in Psychology, 36, 324-338. DOI 10.1007/s12144016-9421-7.

Sumera, M. (2013). Perbuatan Kekerasan/Pelecehan Seksual Terhadap Perempuan. Lex et Societatis, I(2), 39-49.

Tanbrusel, A.E. Mc Kenzie, R. \& Diekmann, K.A. (2018). Sexual Harassment in Acedemia and Bounded Ethicality Annual Review of Psychology, 70(18), 245270 .

UUD1945. (2003). Undang-Undang No. 20 Tahun 2003 Tentang Sistem Pendidikan Nasional. Jakarta: Sinar Grafika

Wijayanti, E.N. Hanim, W., \& Setiawaty, D. (2013). Gambaran Pencapaian Tugas Perekembangan Siswa SMK Insan Global Jakarta. Jurnal Bimbingan dan Konseling, 2(2), 36-46.

Zainal, A. (2014). Kejahatan Kesusilaan dan Pelecehan Seksual di Tinjau Dari Kebijakan Hukum Pidana. Jurnal Al-`Adl. 7(1), 138-158. 